\title{
EFFECTS OF DROUGHT STRESS ON HYBRIDS OF VIGNA RADIATA AT GERMINATION STAGE
}

\author{
Shehzadi Saima, ${ }^{1,2}$ Guishuang Li ${ }^{1}$ and Guang Wu ${ }^{1 *}$ \\ ${ }^{1}$ College of Life Sciences, Shaanxi Normal University, Xi'an, China \\ 2Institute of Pure and Applied Biology Bahauddin Zakariya University, Multan, Pakistan
}

(Received: April 16, 2018; accepted: August 14, 2018)

\begin{abstract}
Drought is one the critical abiotic factors that reduces the germination, growth and yield of crops. Therefore the present project was designed with the objective to screen the best drought tolerant hybrid of Vigna radiata. Genetic variations for drought tolerance among these hybrids were assessed by simple and efficient technique. Seven hybrids of $V$. radiata $(9801,7002,9706,08003,07007,97012$ and 08007) were used for screening against three levels of drought stress (zero, control), 5\% (-0.05 MPa) and 10\% $(-0.1 \mathrm{MPa})$ induced by Polyethyleneglycol $\left(\mathrm{PEG}_{6000}\right)$. A higher proline content was observed in 07007 $(6.10 \mu \mathrm{g} / \mathrm{g}$ fresh weight) as compared to all other hybrids. Treated seedlings of each hybrid were compared with their respective control to evaluate the differences in their growth under drought. Different parameters such as percentage of germination, germination stress tolerance index (GSI), shoot and root weights (bath fresh and dry) and lengths, root length stress index (RLSI), dry matter stress index (DMSI) and plant height stress index (PHSI) showed considerable variations. Germination percentage, shoot weights, PHSI and DMSI decreased in all hybrids along with the increase of PEG induced drought stress (5\% and 10\% PEG). In contrary, root weights and RLSI were increased under drought. Overall 07007 showed a better performance, and can therefore be classified as a drought tolerant hybrid.
\end{abstract}

Keywords: Water stress - germination stress tolerance index - PEG - legumes - dry matter stress index

\section{INTRODUCTION}

In any region of the world, drought is among the most important stress factors that reduces crop production and has became a more severe problem during the last few decades $[16,24]$. It reduces the average yield of crop plants by more than $50 \%$ [13]. The severity of damage caused by drought varies amongst different crops and at different growth stages [17]. In many crops, the seeds germination is one of the critical phases of plant life which is greatly influenced by drought $[3,22,32]$, particularly water uptake by dry seeds. So, drought plays a crucial role in determining the rate of germination and the establishment of seedlings $[6,25]$. Water stress reduces the rate of water uptake by germinating seeds as has been observed in a number of crop

*Corresponding author; e-mail address: gwu3@snnu.edu.cn 
species such as in Lycopersicon esculentum [36], Triticum aestivum [4], Sorghum [12], Helianthus annus [30], Zea mays [11] and Pisum sativum [28]. Furthermore, drought stress decreases both percentage and the rate of germination [15]. Several experiments have shown that plumule is more sensitive to water stress than any other stress [1].

The selection of different varieties/cultivars based on their drought tolerance has been considered to be a cost effective and efficient way of minimizing agricultural problems [5]. The tolerant cultivars have adaptations for the limited water usage [34]. It is very difficult to screen the water stress resistant varieties under field conditions. Hohl and Peter [18] reported that, in vitro screening approach is a potential economic method to screen large set of germplasm accurately in less time. Richards [33] also suggested that germination is a useful criterion for screening of water stress tolerance. The strategy of development to screen different varieties according to their tolerance to drought was based on the measurement of shoot and root moisture contents and dry matter.

Among the germination experiments, the most common is the germination of seeds under the PEG stress. It is a non-ionic polymer soluble in water and does not penetrate in the plant tissues quickly, therefore it is used commonly to create drought stress in higher plants $[8,40]$. To maintain constant water potential, PEG has been used to simulate osmotic stress in germination trays of seeds throughout the experiment [23]. This water stressed environment created artificially, gave the opportunity to select tolerant genotypes out of a large population [29]. It was demonstrated that the varieties that were tolerant to water stress during the in vitro germination tests were equally tolerant in field conditions [2].

Leguminosae is the second most important family after Poaceae, as it provides about $27 \%$ of the world crops production [8]. Legumes provide approximately $30 \%$ of the daily life protein for human consumption, as well as carbohydrates and lipids. They are also used for production of oils and for forage and fodder for animals [37]. Besides their nutritional importance, legumes are also used successfully in the rotation of crops, that helps improve fertility status of soil through nitrogen fixation. In this relationship nitrogen-fixing bacteria (Rhizobium) and roots of higher plants reduce the atmospheric nitrogen to plant available ammonium [28]. To support the awareness about the importance of this, the United Nations declared 2016 as the International year of pulses [27].

In developing countries water availability to agriculture decreased from $87 \%$ to $73 \%$ during the last three decades [31]. In this situation, it is a race to adopt strategies to get maximum crop productions under stressful environment. Therefore, the present study was performed with the aim to determine the germination responses of Vigna radiata hybrids/breeding lines to water stress by using the PEG technique and to screen the best tolerant hybrids among different hybrids that can be grown successfully in drought prone areas. 


\section{MATERIALS AND METHODS}

The experiment was conducted in a rain protected wire-house of Shaanxi Normal University, Xi'an, China. Seeds of seven cultivars of Vigna radiata (09801, 07002, 9706, 08003, 07007, 97012 and 08007) were obtained from NARC, Islamabad, Pakistan. Seeds of all hybrids were sterilized with $0.1 \%$ sodium hypochlorite before germination. Seeds of each hybrid were allowed to germinate in plastic trays $(90 \times 30$ $\mathrm{cm})$, tetra lined with filter paper supplemented with Rorrison nutrient solution with 0 , $5 \%(-0.05 \mathrm{MPa})$ and $10 \%(-0.1 \mathrm{MPa})$ of $\mathrm{PEG}_{6000}$ (Polyethyleneglycol Fisher, England) to simulate drought stress and the maintenance of uniform osmotic potentials. Twenty seeds of each Vigna hybrid were planted in each of the filter paper lined labeled plastic trays. The experiment was carried out in a completely randomized design under laboratory conditions at $\left(32 \pm 3{ }^{\circ} \mathrm{C}\right)$. Each treatment was replicated thrice. Varying levels of water stress was maintained by adding $160 \mathrm{ml}$ of different concentrations of $\mathrm{PEG}_{6000}$ in plastic trays, respectively. The number of germinated seeds of each cultivar was counted on a daily basis for a period of 10 days. When both radicle and plumule length were approximately $5 \mathrm{~mm}$, the seeds were considered germinated. Germination rate (cumulative through time) was determined by the following [9] for each cultivar. At the end of the experiment, seedlings were harvested and separated into roots and shoots. Fresh weights of shoot and root were recorded and then oven dried at $70{ }^{\circ} \mathrm{C}$ for one week to measure dry weights after complete desiccation.

From the above seedlings the Promptness index (PI), root length stress index (RLSI), germination stress tolerance index (GSI), dry matter stress tolerance index (DMSI), plant height stress index (PHSI) were calculated by following [3].

P.I $=$ nd2 $(1.00)+$ nd4 $(0.75)+n d 6(0.5)+n d 8(0.25)$ where $n$ is the number of seeds germinated at day $d$

$$
\begin{gathered}
\text { GSI }=\frac{\text { P.I.of stressed seeds }}{\text { P.I control seeds }} \times 100, \\
\text { PHSI }=\frac{\text { Plant height of stressed plant }}{\text { Plant height of control plants }} \times 100, \\
\text { PLSI }=\frac{\text { Root length stressed plant }}{\text { Root length of control plants }} \times 100, \\
\text { DMSI }=\frac{\text { Dry matter of stressed plant }}{\text { Dry matter of control plants }} \times 100 .
\end{gathered}
$$


Proline contents were measured by the method described by Bates et al. [10] and expressed as $\mu \mathrm{g} / \mathrm{g}$ fresh weight.

Analysis of variance (ANOVA) was done with above data by using CoStat v 6.3 (CoHort, California, Berkely USA) statistical package. Means were also compared by the method of Snedecor and Cochran [38] and using the least significance difference.

\section{RESULTS}

\section{Germination rate}

Osmotic potentials affected significantly the germination percentage of hybrids of $V$. radiata and their interactions (Tables 1,2 ). Germination of all hybrids started one day after sowing. Different hybrids reached its full germination at $0 \%$ PEG at different time intervals. Increased PEG concentrations considerably reduced the germination percentage of all hybrids relative to their controls (Fig. 1). 07007 and 08007 showed maximum germination (95\%) at $-0.05 \mathrm{MPa}$, while 07002 and 09706 showed minimum germination ( $50 \%$ and $60 \%$, respectively). At the $-0.1 \mathrm{MPa}$ level of stress 07007 and 08003 hybrids had highest germination (90\% and 70\%, respectively) and 07002 , and 97012 showed remarkably reduced and delayed germination percentage ( $20 \%$ and $50 \%$, respectively).

Table 1

Analysis of variance (ANOVA) of the data for germination days of seven cultivars of Vigna radiata under different concentrations of PEG for 10 days

\begin{tabular}{|l|r|c|}
\hline \multicolumn{1}{|c|}{ Source } & DF & MS of Germination \\
\hline Days & 2 & $3456.76^{* * *}$ \\
\hline PEG & 2 & $3949.96^{* * *}$ \\
\hline Cultivar $(\mathrm{Cvr})$ & 6 & $132.34 * * *$ \\
\hline Days * PEG & 4 & $484.06^{* * *}$ \\
\hline Days * Cvr & 12 & $42.73^{* *}$ \\
\hline PEG * Cvr & 12 & $41.72^{* *}$ \\
\hline Days * PEG * Cvr & 24 & $20.11 \mathrm{~ns}$ \\
\hline Error & 124 & 17.17 \\
\hline
\end{tabular}

Table 2

Analysis of variance (ANOVA) of the data of mean square for germination days of seven cultivars of Vigna radiata under different concentrations of PEG for different days

\begin{tabular}{|l|r|c|c|c|}
\hline \multicolumn{1}{|c|}{ Source } & DF & Germination day (1) & Germination day (2) & Germination day (3) \\
\hline PEG & 2 & $3737.39 * * *$ & $771.30 * * *$ & $409.39 * * *$ \\
\hline Cultivar (Cvr) & 6 & $170.32 * * *$ & $26.92 \mathrm{~ns}$ & $20.57 \mathrm{~ns}$ \\
\hline PEG $*$ Cvr & 12 & $36.35 \mathrm{~ns}$ & $29.07 \mathrm{~ns}$ & $16.50 \mathrm{~ns}$ \\
\hline Error & 42 & 19.80 & $16<-$ & 16.25 \\
\hline
\end{tabular}



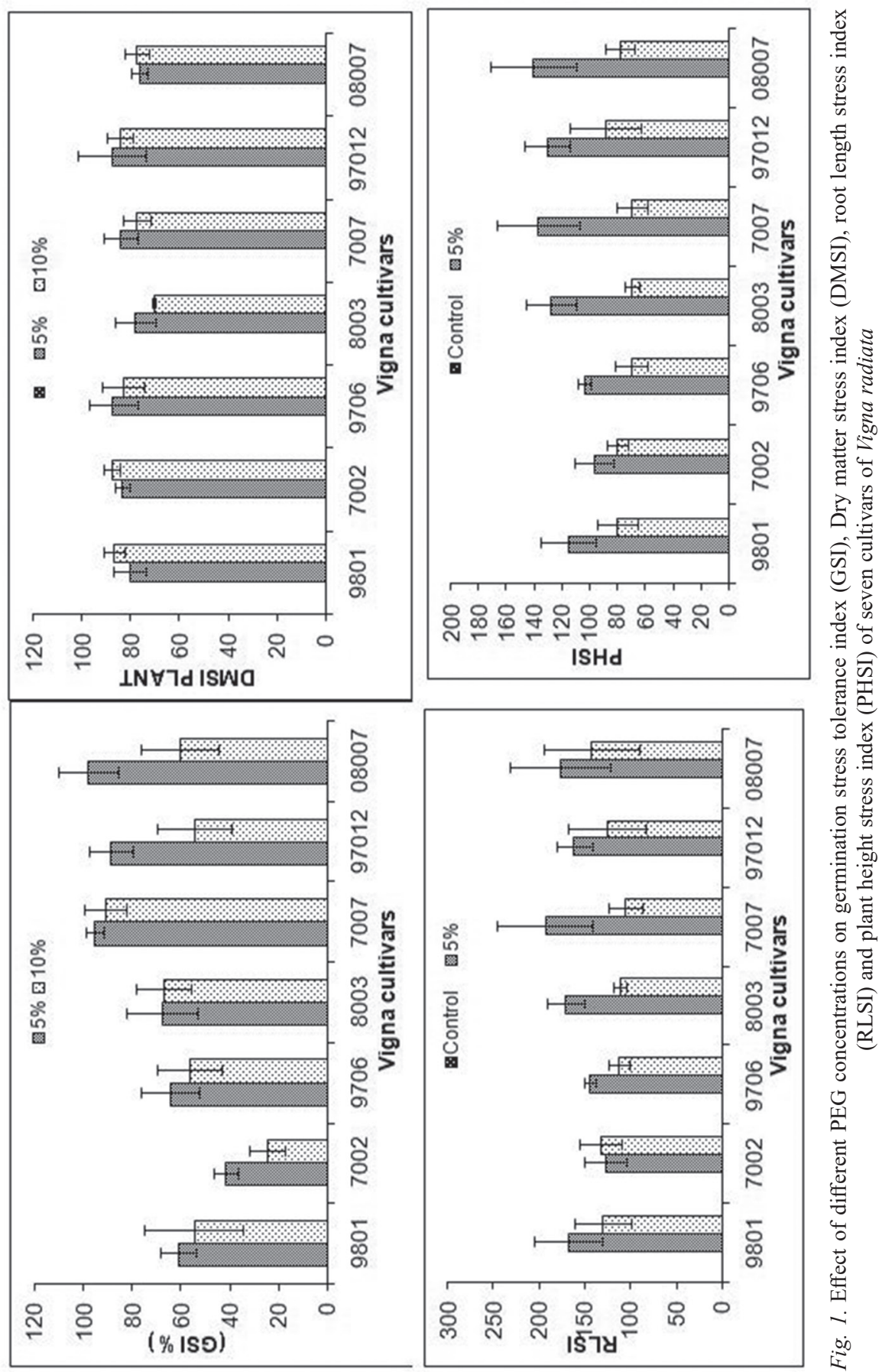

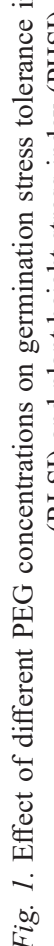



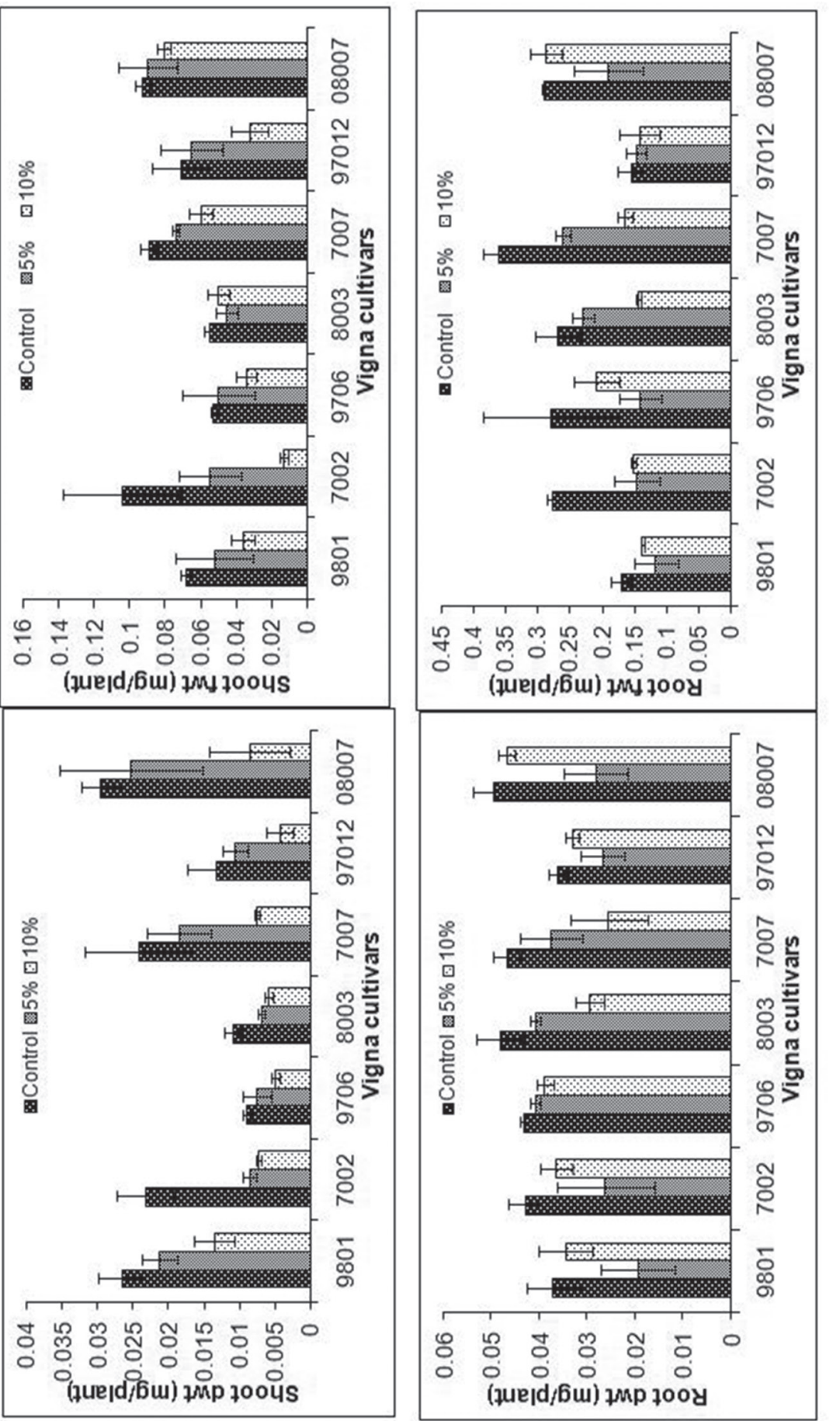


\section{Fresh and dry biomass}

The analysis of variance revealed the significant effects of drought stress and the interaction of PEG concentration with hybrids on shoot weight (Table 3). At different concentration of PEG, the hybrids showed different shoot fresh and dry weights.

09801, 07007 and 08007 hybrids had higher weights, both fresh and dry, at -0.05 $\mathrm{MPa}$ stress, compared to the rest of hybrids that exhibited greater reduction in weights. However, the reduction in both fresh and dry weights was hybrid specific (Fig. 2). At higher concentration of PEG (10\%), all hybrids showed a decline in weight but this reduction was more prominent in 07002, 09706, 08003 and 97012.

The effect of PEG stress was significant on root fresh and dry weights but the hybrids and their interaction were not significant according to the overall analysis of variance (Table 3 ).

\section{Stress Indices}

PEG significantly influenced the DMSI and GSI (Table 4). Increase in stress level decreased the DMSI of shoot in all hybrids, while DMSI of root increased with increase concentration of PEG (Fig. 3). PEG in all cultivars reduced germination significantly due to imposition of drought stress (Table 3). The minimum values of GSI were recorded at $10 \%$ PEG that were significantly lower than at $5 \%$ concentration. Among all the hybrids 08003 showed maximum GSI at both concentrations.

Table 3

Analysis of variance (ANOVA) of the data of mean square for fresh and dry biomass of shoots and roots of seven cultivars of Vigna radiata under different concentrations of PEG for 10 days

\begin{tabular}{|l|c|c|c|c|c|}
\hline \multicolumn{1}{|c|}{ Source } & DF & Shoot Fresh Wt & Shoot Dry Wt & Root Fresh Wt & Root Dry Wt \\
\hline PEG & 2 & $181199.3 * * *$ & $935.19^{* * *}$ & $1307.62^{* * *}$ & $20.07^{* * *}$ \\
\hline Cultivar $(\mathrm{Cvr})$ & 6 & $492.264 \mathrm{~ns}$ & $7.60 \mathrm{~ns}$ & $15.90 \mathrm{~ns}$ & $0.39 \mathrm{~ns}$ \\
\hline PEG $*$ Cvr & 12 & $519.08571^{*}$ & $12.63 \mathrm{~ns}$ & $9.45^{*}$ & $0.26 \mathrm{~ns}$ \\
\hline Error & 42 & 250.59 & 6.82 & 4.87 & 0.22 \\
\hline
\end{tabular}

Table 4

Analysis of variance (ANOVA) of the data of mean square for germination stress tolerance index (GSI), plant height stress tolerance index (PHSI), root length stress tolerance index (RLSI) and dry matter stress tolerance index (DMSI) of seven hybrids of Vigna radiata under different concentrations of PEG for 10 days

\begin{tabular}{|l|c|c|c|c|c|}
\hline \multicolumn{1}{|c|}{ Source } & DF & GSI & PHSI & RLSI & DMSI \\
\hline PEG & 1 & $19543.28 * * *$ & $23679.22 * * *$ & $57550.55 * * *$ & $14971.4 * * *$ \\
\hline Cultivar $(\mathrm{Cvr})$ & 6 & $199.01 \mathrm{~ns}$ & $158.76 * * *$ & $133.91 \mathrm{~ns}$ & $170.70 \mathrm{~ns}$ \\
\hline PEG $*$ Cvr & 6 & $279.37 \mathrm{~ns}$ & $115.88 * *$ & $404.05 \mathrm{~ns}$ & $93.82 \mathrm{~ns}$ \\
\hline Error & 28 & 180.25 & 23.00 & 195.01 & 123.94 \\
\hline
\end{tabular}



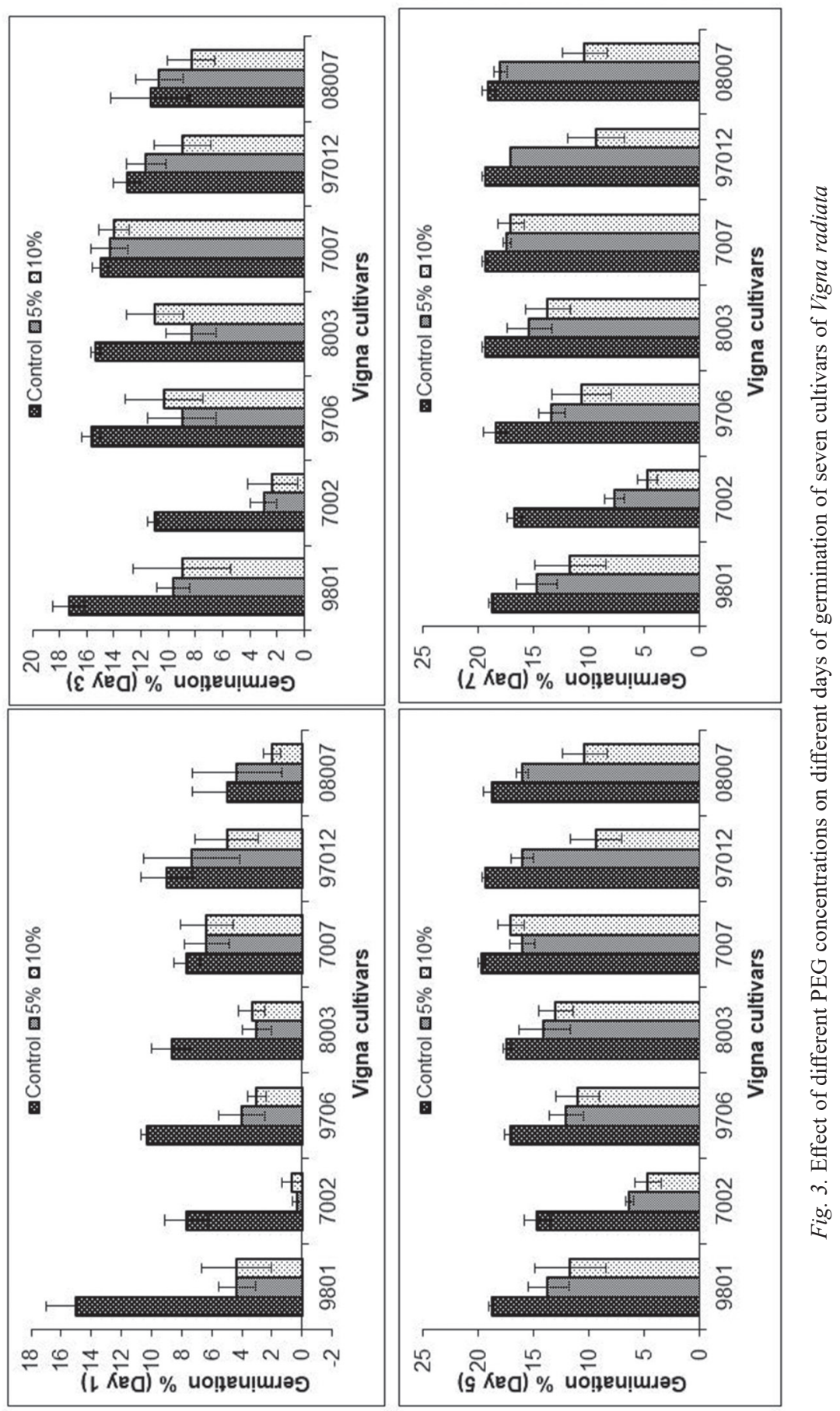

Acta Biologica Hungarica 69, 2018 


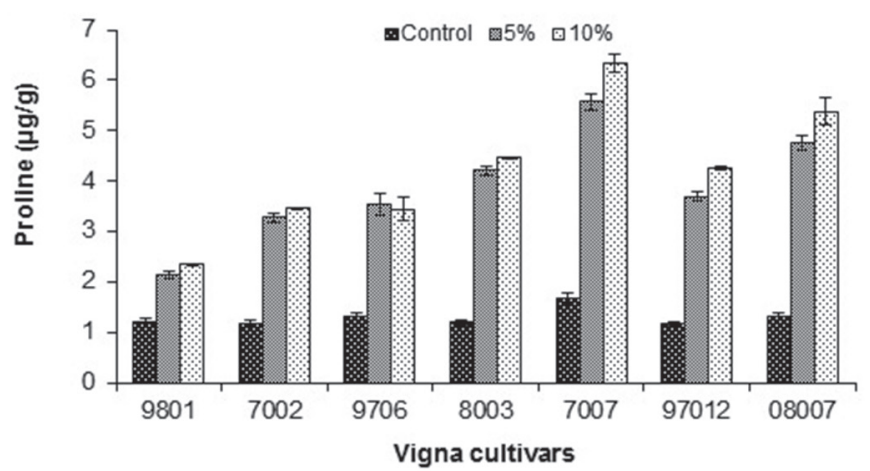

Fig. 4. Effect of different PEG concentrations on proline contents of seven cultivars of Vigna radiata

A significant effect of PEG, inter-hybrid variation and their interaction for plant height stress index was found (Table 4). All cultivars showed reduction in PHSI on imposition of stress however 07007 and 08007 hybrids showed maximum PHSI at 5\% PEG concentration, mean while 09801, 07002 and 97012 had largest PHSI at $10 \%$ concentration. RLSI of all the cultivars was reduced significantly due to drought stress and this became more evident at 10\% PEG concentration (Fig. 4). Although not significant but 07007 showed maximum RLSI than the rest of the hybrids.

Higher proline contents were also observed in 07007 as shown in Table 5.

Table 5

Analysis of variance (ANOVA) of the data of mean square for Proline contents of seven hybrids of Vigna radiata under different concentrations of PEG for 10 days

\begin{tabular}{|l|c|c|}
\hline \multicolumn{1}{|c|}{ Source } & DF & Proline \\
\hline PEG & 1 & $27341.15^{* * *}$ \\
\hline Cultivar $(\mathrm{Cvr})$ & 6 & $201.01^{*}$ \\
\hline PEG ${ }^{*} \mathrm{Cvr}$ & 6 & $305.42^{*}$ \\
\hline Error & 28 & 179.03 \\
\hline
\end{tabular}

\section{DISCUSSION}

In order to create uniform osmotic stress, polyethylene glycol (PEG) could be used as a strong water stress simulator as it reflects the type of stress created by a drying soil [14]. PEG-6000 was also used to create the same drought stress in the present investigation as most of the scientists [19] used it for the creation of water deficit environment under laboratory conditions. In a stressful environment, development of a crop mainly depends on the germination of seeds and the establishment of seedlings. The germination process consists of two stages; first comes the enzymatic hydrolysis of stored food material and the second step is the formation of new tissues 
by hydrolysis [17]. Water shortage affects enzymatic activity and, in turn the percentage of germination, cell division and embryo formation, and radicle and plumule elongation also decreases a more negative osmotic potential [7]. Therefore, it is necessary to develop effective screening criteria at early growth stages to get the maximum yield [9].

In the present study, hybrids showed impressive variation in their tolerance to drought stress produced by PEG-6000, regarding germination rate, shoot and root weights, GSI, PHSI and DMSI. All these parameters decreased remarkably when applying increasing PEG-6000 concentrations. Many other researchers have also described similar results, revealing that increased concentrations of PEG severely reduced seeds germination and seedling establishment, as it hampered the water availability [36]. RLSI increased at $-0.05 \mathrm{MPa}$ in all cultivars, although different hybrids showed different performance under stress environment [22]. The reason of the increase in root length was that roots are the first place to encounter water stress and as an adaptive strategy in water stress tolerance plants reduced shoot growth and promoted the root growth [12]. In addition, longer roots might be supported through the accumulation of biomass by absorbing water from the medium under limited water conditions [5]. According to Rehman et al. [31], the length of roots at the seedling stage can be used as to estimate their growth under field conditions. Ahmad et al. [3] suggested GSI as a powerful drought tolerance measurement parameter to screen large germplasm. The variations in the hybrid performance assessed by growth of seedlings (i.e. dry biomass of shoot a root, root length and plant height] showed that seedling growth is an efficient and a reliable information when screening large number of hybrids for water stress tolerance. The more the degree of drought (i.e. 10\%] the more reduction in plant biomass and plant height is found. Several studies are consistent with the present results, indicating that water stress significantly decreased the biomass and growth of higher plants [35]. Certain varieties of the same species have the genetic potential to keep the higher germination rate and growth under drought, hence are considered as drought tolerant. Growth tolerance indices and germination percentages can aid in finding this genetic potential in diverse germplasm. The results of this study are similar to those of other experiments done on different plants, i.e. such as in chickpea [20], wheat [39], [21] sunflower and Zea mays [11, 22]. The proline content was higher in an intolerant hybrid which has the ability to withstand the drought tolerance. Naidu et al. [26] also observed an increase in the proline content of Vigna radiata when exposed to drought stress.

By measuring seedling traits contributing to drought tolerance screening, it was found that 07007 is the most resistant and 07002 is the most sensitive hybrid. Based on the present investigations, it can be concluded that the screening of hybrids can be performed at germination stages by using correlated attributes of germination, plant biomass and various stress indices under drought conditions. Selection of these critera would be more economical, would need less time and less laboratory work to screen the large germplasm at early growth stage. Our present findings may help Vigna breeders by providing a guideline for the cultivation of more tolerant hybrids in water stress areas. 


\section{REFERENCES}

1. Abdoli, M., Saeidi, M. (2012) Effects of water deficiency stress during seed growth on yield and its components, germination and seedling growth parameters of some wheat cultivars. Intl. J. Agri. Crop Sci. 4, 1110-1118.

2. Agili, S., Nyende, B., Ngamau, K., Masinde, P. (2012) Selection, yield evaluation, drought tolerance indices of orange-flesh sweet potato (Ipomoea batatas Lam) Hybrid clone. Nutr. Food Sci. 2, 138.

3. Ahmad, S., Ahmad, R., Ashraf, M. Y., Ashraf, M., Waraich, E. A. (2009) Sunflower (Helianthus annuus L.) response to drought stress at germination and growth stages. Pak. J. Bot. 41, 647-654.

4. Anupamaa, A., Bhugrab, S., Lallb, B., Chaudhury, S., Chugh, A. (2018) Assessing the correlation of genotypic and phenotypic responses of rice varieties under drought stress. Plant Physiol. Biochem. 127, 343-354

5. Ashraf, M., Bokhari, H., Cristiti, S. N. (1992) Variation in osmotic adjustment of lentil (Lens culinaris Medic) in response to drought. Acta Bot. Neerl. 41, 51-62.

6. Ashraf, M. Y., Akhtar, K., Hussain, F., Iqbal, J. (2006) Screening of different accessions of three potential grass species from Cholistan desert for salt tolerance. Pak. J. Bot. 38, 1589-1597.

7. Avramova, V., Abd-Elgawad, H., Zhang, Z., Fotschki, B., Casadevall, R., Vergauwen, L., Knapen, D., Taleisnik, E., Guisez, Y., Asard, H., Beemster, G. T. S. (2015) Drought induces distinct growth response, protection, and recovery mechanisms in the maize leaf growth zone. Plant Physiol. 169, 1382-1396.

8. Badiane, F. A., Diouf, D., Sane, D., Diouf, O., Goudiaby, V., Diallo, N. (2004) Screening cowpea [Vigna unguiculata (L.) Walp.] varieties by inducing water deficit and RAPD analyses. Afr. J. Biotechnol. 3, 174-178.

9. Bashir, N., Mahmood, S., Zafar, Z. A., Rasul, S., Manzoor, H., Athar, H. R. (2016) Is drought tolerance in maize (Zea mays L.) cultivars at the juvenile stage maintained at the reproductive stage? Pak. J. Bot. 48, 1385-1392.

10. Bates, L. S., Waldrem, R. P., Teare, I. D. (1972) Report of determination of free proline in water stress studies. Plant and Soil 39, 205-208.

11. Batool, N., Ilyas, N., Noor, T., Saeed, M., Mazhar, R., Bibi, F., Shahzad, A. (2014) Evaluation of drought stress effects on germination and seedling growth of Zea mays L. Int. J. Biosci. 5, 203-209.

12. Bibi, A., Sadaqat, H. A., Tahir, M. H. N., Akram, H. M. (2012) Screening of Sorghum bicolor Var Moench for drought tolerance at seedling stage in polyethyleneglycol. J. Animal Plant Sci. 22, 671-678.

13. Cavallaroa, V., Barbera, A. C., Maucieri, C., Gimmaa, G., Scalisi, C., Patanea, C. (2016) Evaluation of variability to drought and saline stress through the germination of different ecotypes of carob (Ceratonia siliqua L.) using a hydrotime model. Ecol. Eng. 95, 557-566.

14. Cooper, M., Gho, C., Leafgren, R., Tang, T., Messina, C. (2014) Breeding drought-tolerant maize hybrids for the US corn-belt: discovery to product. J. Exp. Bot. 65, 6191-6204.

15. Delachiave, M. E. A., De Pinho, S. Z. (2003) Germination of Seena occidentalis link: seeds at different osmotic potential levels. Braz. Arch. Techno. 46, 163-166.

16. Ebrahimi, D. M., Shirmohammadi, E. (2017) Effectiveness of plant growth promoting rhizobacteria on Bromus tomentellus Boiss seed germination, growth and nutrients uptake under drought stress. S. Afr. J. Bot. 113, 11-18.

17. Fahad, S., Bajwa, A. A., Nazir, U., Anjum, S. A., Farooq, A., Zohaib, A., Sadia, S., Nasim, W., Adkins, S., Saud, S., Ihsan, M. Z., Alharby, H., Wu, C., Wang, D., Huang, J. (2017) Crop Production under Drought and Heat Stress: Plant Responses and Management Options. Front. Plant Sci. 8, 1147.

18. Hohl, M., Peter, S. (1991) Water relation of growing maize coleoptiles. Comparison between mannitol and polyethylene glycol 6000 as external osmotica for adjusting turgor pressure. Plant Physiol. 95, 716-722.

19. Hu, F. D., Jones, R. J. (2004) Effects of plant extracts of Bothriochloa pertusa and Urochloa mosambicensis on seed germination and seedling growth of Stylosanthes hamata cv. Verano and Stylosanthes scabra cv. Seca. Aust. J. Agric. Res. 48, 1257-1264. 
20. Kalefetoglu, T., Macar, T., Turan, O., Ekmekci, Y. (2009) Effect of water stress deficit induced by PEG and Nacl on Chickpea (Cicer arietinum L.) cultivars and lines at early seedling stage. G. U.J. Sci. 22, 5-14.

21. Kaya, M. D., Okcu, G., Atak, M., Cikili, Y., Kolsarici, O. (2006) Seed treatments to overcome salt and drought stress during germination in sunflower (Helianthus annuus L.). Eur. J. Agron. 24, 291-295.

22. Khayatnezhad, M., Gholamin, R., Jamaatie-Somarin, S. H., Zabihi-Mahmoodabad, R. (2010) Effects of PEG stress on corn cultivars (Zea mays L.) at germination stage. World Appl. Sci. J. 11, 504-506.

23. Kulkarni, M., Deshpande, U. (2007) In vitro screening of tomato genotypes for drought resistance using polyethylene glycol. Afr. J. Biotechnol. 6, 691-696.

24. Lafitte, H. R., Yongsheng, G., Yan, S., Li, Z. K. (2007) Whole plant responses, key processes, and adaptation to drought stress: the case of rice. J. Exp. Bot. 58, 169-175.

25. Macart, K., Turan, Y., Ekmekci, T. (2009) Effect of water deficit induced by PEG and $\mathrm{NaCl}$ on chickpea (Cicer arietinum L.) cultivar and lines at early seedling stage. Gazi Uni. J. Sci. 22, 5-14.

26. Naidu, T. C. M., Raju, N., Narayanan, A. (2001) Screening of drought tolerance in green gram (Vigna radiata L. Wilczek) genotypes under receding soil moisture. Indian J. plant physiol. 6, 197-201.

27. Naseer, S., Nisar, A., Ashraf, M. (2001) Effect of Salt Stress on Germination and Seedling Growth of Barley (Hordeum vulgare L.). Pak. J. Biol. Sci. 4, 359-360.

28. Petrovic, G., Jovicic, D., Nikolic, Z., Tamindzic, G., Ignjatov, M., Milosevic, D., Milosevic, B. (2016) Comparative study of drought and salt stress effects on germination and seedling growth of pea. Genetika 48, 373-381.

29. Rajendran, R. A., Muthiah, A., Manickam, P., Shanmugasundaram, A., John, J. (2011) Indices of drought tolerance in sorghum (Sorghum bicolor L. Moench) genotypes at early stages of plant growth. Res. J. Agric. Biol. Sci. 7, 42-46.

30. Rauf, S., Sadaqat, H. A., Khan, I. A. (2008) Effect of moisture regimes on combining ability variations of seedling traits in sunflower (Helianthus annuus L.). Can. J. Plant Sci. 88, 323-329.

31. Rehman, A., Jingdong, L., Shahzad, B., Chandio, A. A., Hussain, I., Nabie, G., Iqbal, M. S. (2015) Economic perspectives of major field crops of Pakistan: An empirical study. Pacific Science Review B: Humanities and Social Sciences 1, 145-158.

32. Ribeiro, N. M., Torres, B. A., Ramos, S. K., Santos, P. H., Simoes, C. T., Monquero, P. A. (2018) Differential susceptibility of morning glory (Ipomoea and Merremia) species to residual herbicides and the effect of drought periods on efficacy. Aust. J. Crop Sci. 12, 1090-1098.

33. Richards, R. A. (1978) Variation between and within species of rapeseed (Brassica campestris and B. napus) in response to drought stress: Physiological and physicochemical characters. Aust. J. Agric. Res. 29, 491-501.

34. Shaheen, R., Hood-Nowotny, R. C. (2005) Effect of drought and salinity on carbon isotope discrimination in wheat cultivars. Plant Sci. 168, 901-909.

35. Shamim, F., Saqlan, S. M., Athar, H. R., Waheed, A. (2014) Screening and selection of tomato genotypes/cultivars for drought tolerance using multivariate analysis. Pak. J. Bot. 46, 1165-1178.

36. Shu-han, Z., Xue-feng, X., Ye-min, S., Jun-lian, Z., Chao-zhou, L. (2018) Influence of drought hardening on the resistance physiology of potato seedlings under drought stress. J. Integr. Agric. 17, 336-347.

37. Smykal, P., Aubert, G., Burstin, J., Coyn, C. J., Ellis, N. T. H., Flavell, A. J., Ford, R., Hybl, M., Macas, J., Neumann, P., Mc-Phee, K. E., Redden, R. J., Rubiales, D., Weller, J. L., Warkentin, T. L. (2012) Pea (Pisum sativum L.) in the Genomic Era. Agronomy 2, 74-115.

38. Snedecor, G. W., Cochran, W. G. (1980) Statistical methods. $7^{\text {th }}$ edition, Iowa State University Press, Ames, Iowa.

39. Soltani, A., Gholipoor, M., Zeinali, E. (2006) Seed reserve utilization and seedling growth of wheat as affected by drought and salinity. Environ. Exp. Bot. 55, 195-200.

40. Verslues, P. E., Agarwal, M., Katiyar-Agarwal, S., Zhu, J., Zhu, J. K. (2006) Methods and concepts in quantifying resistance to drought, salt and freezing, abiotic stresses that affect plant water status. Plant J. 45, 523-539. 